\title{
Zémaria, a tosse e a fé no tratamento da tuberculose
}

\section{Prezado Editor:}

Vez por outra, somos surpreendidos por certas concepções que desafiam o bom senso. Ainda que inocentes ou imbuídas da melhor das boas vontades, resultam em prejuízos enormes para a saúde individual ou coletiva. Alguém já afirmou que "o inferno está cheio de homens de boa vontade".

No passado, por não poder processá-las no meu inquieto metabolismo mental, tais concepções provocavam um sentimento de revolta, culminando quase sempre com reações intempestivas, de resultados imprevisíveis.

Lembro-me, a título de exemplo, da tentativa de modificar um costume que observei ao viver num dos interiores deste Brasil, da parteira colocar esterco seco de boi para cicatrizar o cordão umbilical dos recém-nascidos. Aquela conduta paralisava mais rápido o sangramento, porém com alto risco de infecção por esporos do tétano. Fui tão infeliz na forma de combater o costume, só realçando o risco e não formulando uma opção de garroteamento, que seis meses depois a parteira continuava com a mesma prática e eu fracassado como educador.

O tempo passa, a barba cresce, amadurecemos com o experimentar de erros e acertos e, com isso, nos tornamos mais cuidadosos e tolerantes no debate das idéias, porém mais maquiavélicos no proceder.

Quem comigo convive na corporação pneumológica deve enumerar diversas polêmicas e debates que provoquei. Em minha autodefesa, posso garantir que, pelo menos, elas guardam certa conseqüencia, na defesa do coletivo sobre o interesse individual ou de grupo, além de determinada capacidade de revisão crítica. Afinal, uma prisão, as dificuldades para retomar a profissão após um período de militância política e em especial as derrotas do Corinthians e para os bacilos multirresistentes, me ensinaram a aprender com os fracassos.

Não sou, entretanto, isento de recaídas e recidivas.

Uma das mais recentes, recorreu-me ao ler um livreto de uma seita com grande influência sobre a população nipônica. Papel de boa qualidade, excelente arte gráfica e redação apurada denunciavam cômodos recursos e um público de conhecimentos acima da média. O mesmo não podia qualificar o conteúdo. Em uma de suas seções, letras garrafais anunciavam: TUBERCULOSE: NÃO SE CURA COM MEDICAMENTOS E SIM COM FÉ. O artigo discorria uma série de baboseiras capaz de provocar sérias conseqüencias para leitores eventualmente envolvidos com a tuber- culose, e, concomitantemente estimular os setores irreverentes do meu pensar e reagir.

Tudo isso no momento em que se desenvolve um esforço nacional em ampliar a descoberta de casos e diminuir a taxa de abandono, exatamente com o tratamento supervisionado. Seria impossível não lembrar das altas taxas de tuberculose na população nipônica, de esquecer do Clemente Ferreira, acumulado de multirresistentes falidos à espera de novas drogas, com as esperanças excitadas com as notícias das reais possibilidades da vacina antigênica do Dr. Célio Silva, de Ribeirão Preto.

Algo precisava ser feito, talvez conseguir uma correção conceitual, quem sabe conhecer aquela FÉ, de mais ou de menos.

Tento por telefone um contato com o redator responsável, uma pessoa educada me atende, informando que o mesmo estava viajando e chegaria dentro de alguns dias. Insistiu sobre o assunto e, informada, aconselhou-me um contato pessoal com o tal redator, marcando uma entrevista.

A consulta de Zémaria, que aparece sem avisar, aconteceu exatamente quando me preparava para a tal entrevista.

O paciente, que aqui chamo pelo codinome de Zémaria, é uma daquelas figuras que só na tuberculose podemos encontrar. Formado na Febem, com doutorado no Carandiru, experimentou diversas prisões e condenações em quase todos os artigos referentes a furto e roubo. Acompanho Zémaria há anos. Nunca marca consulta, aparece episodicamente, ora sozinho, ora acompanhado por escolta policial.

Fez da tuberculose um lenitivo para escapadas e sobrevivência. Vivesse na era pré-quimioterápica, provavelmente seria, como contam os velhos tisiologistas, um vendedor de escarro positivo para ludibriar a Previdência, pois naquela época a tuberculose dava aposentadoria definitiva. Utilizou, entretanto, muito bem sua doença. Quando sentia fome e dificuldades para roubar, sabia exatamente como provocar uma hemoptise, correndo do Centro de São Paulo até o Hospital do Mandaqui, onde chegava no início da noite, suado e febril. Conhecia os plantonistas e sabia quais os mais condescendentes para interná-lo. Refeito e melhorado, não concluía o tratamento no Posto referenciado, pois necessitava de sua doença ativa para novos retornos. Preso, ameaçava os policiais e outros 
detentos, alegando a sua condição de transmissor da tuberculose. O escarro três cruzes confirmava a ameaça.

Zémaria manteve uma tuberculose crônica por quase cinco anos, sem nunca apresentar resistência bacilar. Tal sorte e uma condenação prolongada foram a desdita de Zémaria, o tuberculoso profissional. Lembro que em uma visita ao Hospital do Presídio o encontrei, emagrecido e desidratado, mas usando medicação regularmente, concluindo nove meses de tratamento com um esquema RHE acrescido de $\mathrm{S}$, o E pela intolerância a $\mathrm{Z}$ e a S, por segurança devidos aos repetidos abandonos anteriores e extensas cavitações bilaterais. Nunca mais positivou. Restaramlhe resíduos bronquiectásicos e funcionais, a capacidade de provocar hemoptise com esforço físico e aspecto emagrecido e tísico.

Zémaria era a inspiração de que precisava.

Convoquei-o para me acompanhar na entrevista com o tal reverendo, devidamente orientado e refastelado por um almoço em uma churrascaria popular.

Cordialidade e urbanidade marcaram o início da conversa num escritório distinto e arrumado. Um nissei de óculos e até simpático, dizendo ser o responsável pela revista, porém não o autor daquele artigo.

Tentava argumentar:

- Veja, senhor, ao que me parece, sua igreja tem muitos fiéis. Tosse Zémaria. Me preocupa porque, quanto mais eles são, maior a possibilidade de tuberculose entre eles. Tosse Zémaria. Veja, pastor, a tuberculose matou muita gente no passado, metade dos doentes morriam antes de surgirem os medicamentos. Tosse Zémaria. Depois deles as mortes reduziram ao mínimo. Tosse Zémaria. Os modernos medicamentos reduziram o tempo de tratamento. Tosse Zémaria. Atualmente, o HIV vinha aumentando a incidência da doença. Tosse Zé- maria. Que se complica com a emergência de formas multirresistentes com chances de cura bem mais reduzidas. Tosse Zémaria... Tosse...

Lá pelo vigésimo Tosse Zémaria, uma súbita inquietude explodiu no pastor que, interrompendo meus argumentos, perguntou, virando-se para meu acompanhante.

- Senhor José Maria, V. é médico, está doente, precisa de ajuda?

Pronto, era o mote que esperava!

- Não Pastor, Zémaria é um doente crônico que leu sua Revista e quer conhecer a Fé que cura. O problema é que, neste ambiente fechado e ele tossindo, é possível que o Pastor seja contaminado com germes multirresistentes. $\mathrm{O}$ que não deve importar, pois a sua Igreja domina um modo de tratamento bastante eficaz, eu gostaria inclusive de presenciar este tipo de tratamento, pois...

Evidentemente, aquele religioso não era tão mentecapto para desconhecer uma provocação. Mudou a estação do ambiente. Acabei sendo convidado a me retirar, sem cordialidade ou urbanismo.

Saímos, eu e Zémaria, ele gargalhando e eu sorrindo, com um gostoso sentimento do dever cumprido.

FERNANDO AuguSTO FIUZA DE MELO
Médico do Instituto Clemente Ferreira e do
Hospital do Servidor Público Estadual - São Paulo
Doutor em Medicina pela Escola Paulista de Medicina - Unifesp

Endereço para correspondência - Instituto Clemente Ferreira (ICF), Divisão de Tisiologia e Pneumologia Sanitária, Secretaria de Estado da Saúde de São Paulo, Rua da Consolação, 717 - 01301-000 - São Paulo, SP. Tel./Fax: (11) 257-8096/258-7644/257-6579; e-mail: fiuza@osite.com.br 